\title{
A multi-resolution assessment of the Community Multiscale Air Quality (CMAQ) model v4.7 wet deposition estimates for 2002-2006
}

\author{
K. W. Appel ${ }^{1}$, K. M. Foley ${ }^{1}$, J. O. Bash ${ }^{1}$, R. W. Pinder ${ }^{1}$, R. L. Dennis ${ }^{1}$, D. J. Allen ${ }^{2}$, and K. Pickering ${ }^{3}$ \\ ${ }^{1}$ Atmospheric Modeling and Analysis Division, National Exposure Research Laboratory, Office of Research and \\ Development, US Environmental Protection Agency, RTP, NC, USA \\ ${ }^{2}$ Department of Atmospheric and Oceanic Science, University of Maryland, College Park, MD, USA \\ ${ }^{3}$ Atmospheric Chemistry and Dynamics Branch, NASA-Goddard, Greenbelt, MD, USA
}

Received: 15 October 2010 - Published in Geosci. Model Dev. Discuss.: 9 December 2010

Revised: 11 April 2011 - Accepted: 20 April 2011 - Published: 3 May 2011

\begin{abstract}
This paper examines the operational performance of the Community Multiscale Air Quality (CMAQ) model simulations for 2002-2006 using both 36-km and 12-km horizontal grid spacing, with a primary focus on the performance of the CMAQ model in predicting wet deposition of sulfate $\left(\mathrm{SO}_{4}^{=}\right)$, ammonium $\left(\mathrm{NH}_{4}^{+}\right)$and nitrate $\left(\mathrm{NO}_{3}^{-}\right)$. Performance of the wet deposition estimates from the model is determined by comparing CMAQ predicted concentrations to concentrations measured by the National Acid Deposition Program (NADP), specifically the National Trends Network (NTN). For $\mathrm{SO}_{4}^{=}$wet deposition, the CMAQ model estimates were generally comparable between the $36-\mathrm{km}$ and $12-\mathrm{km}$ simulations for the eastern US, with the $12-\mathrm{km}$ simulation giving slightly higher estimates of $\mathrm{SO}_{4}^{=}$wet deposition than the $36-\mathrm{km}$ simulation on average. The result is a slightly larger normalized mean bias (NMB) for the $12-\mathrm{km}$ simulation; however both simulations had annual biases that were less than $\pm 15 \%$ for each of the five years. The model estimated $\mathrm{SO}_{4}^{=}$wet deposition values improved when they were adjusted to account for biases in the model estimated precipitation. The CMAQ model underestimates $\mathrm{NH}_{4}^{+}$wet deposition over the eastern US, with a slightly larger underestimation in the 36-km simulation. The largest underestimations occur in the winter and spring periods, while the summer and fall have slightly smaller underestimations of $\mathrm{NH}_{4}^{+}$ wet deposition. The underestimation in $\mathrm{NH}_{4}^{+}$wet deposition is likely due in part to the poor temporal and spatial representation of ammonia $\left(\mathrm{NH}_{3}\right)$ emissions, particularly those
\end{abstract}

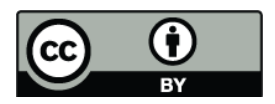

Correspondence to: K. W. Appel (appel.wyat@epa.gov) emissions associated with fertilizer applications and $\mathrm{NH}_{3}$ bidirectional exchange. The model performance for estimates of $\mathrm{NO}_{3}^{-}$wet deposition are mixed throughout the year, with the model largely underestimating $\mathrm{NO}_{3}^{-}$wet deposition in the spring and summer in the eastern US, while the model has a relatively small bias in the fall and winter. Model estimates of $\mathrm{NO}_{3}^{-}$wet deposition tend to be slightly lower for the $36-\mathrm{km}$ simulation as compared to the $12-\mathrm{km}$ simulation, particularly in the spring. The underestimation of $\mathrm{NO}_{3}^{-}$wet deposition in the spring and summer is due in part to a lack of lightning generated NO emissions in the upper troposphere, which can be a large source of NO in the spring and summer when lightning activity is the high. CMAQ model simulations that include production of $\mathrm{NO}$ from lightning show a significant improvement in the $\mathrm{NO}_{3}^{-}$wet deposition estimates in the eastern US in the summer. Overall, performance for the $36-\mathrm{km}$ and $12-\mathrm{km}$ CMAQ model simulations is similar for the eastern US, while for the western US the performance of the $36-\mathrm{km}$ simulation is generally not as good as either eastern US simulation, which is not entire unexpected given the complex topography in the western US.

\section{Introduction}

Atmospheric deposition of sulfur and nitrogen cause deleterious impacts on terrestrial and aquatic ecosystems due to acidification and excess nutrients (Lovett and Tear; 2008, Driscoll et al., 2001, 2003; Fenn et al., 2003). Sulfur deposition from $\mathrm{SO}_{2}$ and $\mathrm{SO}_{4}^{=}$emissions contributes to acidification and nitrogen deposition from nitrogen oxide $\left(\mathrm{NO}_{\mathrm{x}}\right)$ and ammonia $\left(\mathrm{NH}_{3}\right)$ emissions contribute to acidification and excess

Published by Copernicus Publications on behalf of the European Geosciences Union. 
nitrogen nutrients. Estimates of wet and dry deposition of nitrogen and sulfur are needed for sensitive ecosystems, as total deposition estimates are used to assess whether current or projected pollutant levels exceed a point where significant harmful effects on sensitive elements of the environment are likely to occur (Geiser et al., 2010). Monitoring of wet deposition is relatively sparse and monitoring of dry deposition is extremely sparse, contributing to significant interpolation errors when these data are used to estimate deposition in unmonitored areas. Thus, a regional air quality model like the Community Multiscale Air Quality (CMAQ; Byun and Schere, 2006) model can be used to provide a more spatially complete estimate of total deposition to the sensitive ecosystems. However, the model estimates must first be evaluated to establish the credibility of the model in replicating the observed wet deposition.

Evaluating the ability of the air quality model to replicate observed net (wet + dry) deposition is difficult. The National Atmospheric Deposition Program (NADP; http://nadp.sws. uiuc.edu) monitoring sites provide the most complete spatial coverage of observed wet deposition across the US on a temporal scale suitable for air quality model evaluations. Evaluation of dry deposition is even more challenging because monitoring network (e.g. Clean Air Status and Trends Network) dry deposition levels are based on modeled values of deposition velocity and hence are not a true measure of dry deposition. Therefore, this work focuses on wet deposition to provide a test of the ability of the model to mix, transport, transform and scavenge the pollutant emissions at the regional scale. Many sensitive ecosystems are in complex terrain where orographic effects influence the precipitation patterns and consequently wet deposition. Thus, quantifying precipitation biases as part of the wet deposition evaluation is critical.

This paper examines the performance of the CMAQ model sulfate $\left(\mathrm{SO}_{4}^{=}\right)$, nitrate $\left(\mathrm{NO}_{3}^{-}\right)$and ammonium $\left(\mathrm{NH}_{4}^{+}\right)$wet deposition estimates for the 2002-2006 period over the continental United States (CONUS) using two model grid-spacing options, namely $12-\mathrm{km}$ and $36-\mathrm{km}$ grid spacing. The performance of the CMAQ model estimates is examined temporally using various averaging periods (i.e. monthly, seasonal, annual and multi-annual) and spatially across different regions, as the model performance can vary significantly in space. In cases where deficiencies in model performance are identified, model improvements, such as the production of $\mathrm{NO}_{\mathrm{x}}$ from lightning and inclusion of bi-directional flux of $\mathrm{NH}_{3}$, are tested and their impacts on model performance assessed. Together, these analyses provide insight into the strengths and weaknesses of the CMAQ model in estimating wet deposition of sulfur and nitrogen to sensitive ecosystems.

\section{Input data and model configuration}

\subsection{Meteorology}

The CMAQ model requires gridded meteorological data to provide estimates of various meteorological parameters such as temperature, wind speed and direction, relative humidity and planetary boundary layer (PBL) height. The 5th generation Mesoscale Model (MM5; Grell et al., 1994) is an Eulerian meteorological model that provides estimates of the meteorological parameters required by the CMAQ model, and has been used and tested extensively with the CMAQ model over the past 15 years. For this work, the MM5 version 3.7.4 was used for both the $36-\mathrm{km}$ and $12-\mathrm{km}$ simulations. The 36-km MM5 domain consists of 165 by 129 grid cells covering the entire CONUS, and includes portions of Canada and Mexico. The $12-\mathrm{km}$ domain consists of 290 by 251 grid cells covering the eastern two-thirds of the US, southern Canada and northern Mexico.

Boundary conditions for the 2002-2005 36- $\mathrm{km}$ and 12km MM5 simulations were provided by the 40-km Eta Data Assimilation System (EDAS) data; while the 12-km North American Model (NAM) data were used as boundary conditions for the 2006 36-km and 12-km MM5 simulations, with any missing data filled in using the 32-km North American Regional Reanalysis data (http://www.emc.ncep.noaa. gov/mmb/rreanl/). The 12-km NAM data are preferred for the boundary conditions, but were not available for years prior to 2006. The MM5 simulations utilized the KainFritsch 2 (KF2) cumulus parameterization (Kain, 2004); the asymmetric convective model version 2 (ACM2) PBL scheme (Pleim, 2007a, b); the Reisner 2 explicit microphysics scheme (Reisner et al., 1998); the Dudhia shortwave radiation scheme (Dudhia, 1989); the RRTM longwave radiation scheme (Mlawer et al., 1997); and the Pleim-Xiu land surface model (LSM; PX; Xiu and Pleim, 2001; Pleim and Xiu, 1995). Both the 36-km and 12-km MM5 simulations utilized 34 vertical layers, with the surface layer set at approximately $36 \mathrm{~m}$. The meteorological outputs from both sets of MM5 simulations were processed to create modelready inputs for CMAQ using the Meteorology-Chemistry Interface Processor (MCIP; Otte et al., 2005) version 3.4.

\subsection{Emissions}

The 2002 National Emissions Inventory (NEI) version 3 was used as the primary basis for the 2002-2006 emissions inputs. Version 3 of the 2002 NEI is documented at http://www.epa.gov/ttn/chief/net/2002inventory. html\#documentation. For the major point sources, namely electric generating units, year specific continuous emission monitoring systems data were used. Year specific updates to mobile emissions were done using the MOBILE6 model, and daily estimates of fire emissions based on satellite detection of fires were included as well. $\mathrm{NH}_{3}$ emissions from 
agricultural cropping practices in CMAQ are provided by a separate model based on the Carnegie Mellon University ammonia emission model (Goebes et al., 2003), which are then combined with the NEI. Monthly $\mathrm{NH}_{3}$ emissions from livestock were adjusted according to the inverse-modeling recommendations of Gilliland et al. (2006). For inventories outside of the US, which include Canada, Mexico and offshore emissions, the latest available base year inventories were used. The CMAQ model-ready emissions were created using the Sparse Matrix Operator Kernel Emissions (SMOKE) modeling system (Houyoux et al., 2000).

\subsection{CMAQ model configuration}

The CMAQ simulations were performed at the $36-\mathrm{km}$ horizontal grid spacing for the CONUS, while for the eastern two-thirds of the US a CMAQ simulation using 12-km horizontal grid spacing was performed. Chemical boundary conditions for the $12-\mathrm{km}$ simulation were provided by the $36-\mathrm{km}$ simulation, while boundary conditions for the $36-\mathrm{km}$ CMAQ simulation were obtained from a 2.0 degree by 2.5 degree (latitude-longitude), 24-vertical layer 2002 GEOSChem (Bey et al., 2001) simulation. Since only a single GEOS-Chem simulation was available and boundary data were needed for the 2002-2006 period, the median value of the 2002 GEOS-Chem simulation output were extracted to create "profile" boundary conditions for the CMAQ simulations. The median values were then averaged to create monthly values which were used as boundary conditions for the 36-km CMAQ simulations. As such, the GEOS-Chem data used for the boundary conditions represent non-year specific static monthly values.

The air quality simulations utilized CMAQv4.7 (Foley et al., 2010), the latest version of the model available at that time. The simulations included a 10-day spin-up period for the 36-km simulations, while a 3-day spin-up period was used for the $12-\mathrm{km}$ simulations. The CMAQ simulations were performed using the same horizontal dimensions as their respective meteorology simulation except that the horizontal dimensions were reduced by five grid cells on each of the four lateral boundaries to avoid artifacts that can appear along the domain boundaries in the meteorological simulations. However, unlike the meteorological simulations which utilized 34-vertical layers, the CMAQ simulations used 24vertical layers. The CMAQ model simulations used the AERO5 aerosol module (Carlton et al., 2010), the CarbonBond 05 (CB05) chemical mechanism with chlorine chemistry extensions (Yarwood et al., 2005) and the ACM2 PBL scheme (Pleim, 2007a, b).

\subsection{Assessing model performance}

Assessment of the CMAQ model's wet deposition estimates is accomplished by comparing the simulated wet deposition estimates to observed wet deposition values available from the NADP's National Trends Network (NTN). The NTN measures total weekly wet deposition of several atmospheric pollutants, including $\mathrm{SO}_{4}^{=}, \mathrm{NH}_{4}^{+}$and $\mathrm{NO}_{3}^{-}$. Since all of the $\mathrm{SO}_{2}$ in rainwater is oxidized to $\mathrm{SO}_{4}^{=}$by the time the samples are analyzed for the NTN (high prevalence of oxidants), the CMAQ estimates of $\mathrm{SO}_{4}^{=}$wet deposition include $150 \%$ (based on the ratio of the molecular weights of $\mathrm{SO}_{2}$ and $\mathrm{SO}_{4}^{=}$) of the model estimated $\mathrm{SO}_{2}$ wet deposition to account for the $\mathrm{SO}_{2}$ captured in the observations. Because in solution the favored phase of $\mathrm{NH}_{3}$ is $\mathrm{NH}_{4}^{+}$at the $\mathrm{pH}$ of rainwater, the CMAQ estimates of $\mathrm{NH}_{4}^{+}$wet deposition include $106 \%$ of the model estimated $\mathrm{NH}_{3}$ wet deposition to account for reduced nitrogen (both $\mathrm{NH}_{4}^{+}$and $\mathrm{NH}_{3}$ ) captured in the NTN observations. Likewise, because in solution $\mathrm{HNO}_{3}$ reacts with water and dissociates to $\mathrm{NO}_{3}^{-}$as the favored phase, the CMAQ estimates of $\mathrm{NO}_{3}^{-}$wet deposition include $98.4 \%$ of the model estimated nitric acid wet deposition to account for $\mathrm{NO}_{3}^{-}$captured as nitric acid and converted to $\mathrm{NO}_{3}^{-}$in the NTN measurements.

The NTN consists of approximately 185 sites in the eastern US (east of $110^{\circ} \mathrm{W}$ longitude) and 38 sites in the western US (west of $110^{\circ} \mathrm{W}$ longitude). Only observations that were flagged as valid in the NTN data file were used in the performance analysis. The NTN measures deposition from rain, snow and sleet through a continuously operating wet deposition collector. The collector opens during wet weather to allow precipitation to fall into the bucket, which is later removed for analysis and replaced with a clean collector bucket. Each NTN site is also equipped with a weighingbucket rain gauge to provide a continuous record of rainfall (recorded to the nearest $0.01 \mathrm{in}$ ).

Observations and model estimates are paired in time and space using the EPA's Site Compare program, which is available for download as a tool from the Community Modeling and Analysis System (CMAS) website (http://www. cmascenter.org). Visualization of observations and model estimates, and computation of model performance statistics is accomplished through the use of the Atmospheric Model Evaluation Tool (AMET; Appel et al., 2010), available for download through the CMAS website. It should be noted that observations represent point measurements, while the model values represent grid cell averages. No interpolation or any other type of post-processing has been applied to account for the incommensurability between the observations and the model estimates (e.g. Davis and Swall, 2006).

\subsection{Precipitation bias adjustment}

At least some portion of the error present in the CMAQ estimated wet deposition is due to errors in the precipitation estimates from the meteorological model. Since both the NTN observed and MM5 estimated precipitation data are available for each NTN site, the modeled wet deposition can be adjusted to account for the error present in the model estimated precipitation. This adjustment is accomplished here 
Table 1. Seasonal and annual NMB (\%) for precipitation for the 12-km and 36-km CMAQ model simulations.

\begin{tabular}{|c|c|c|c|c|c|c|c|}
\hline & CMAQ Domain & 2002 & 2003 & 2004 & 2005 & 2006 & $\begin{array}{r}\text { Five-Year } \\
\text { Average }\end{array}$ \\
\hline \multirow{3}{*}{ Winter } & $12-\mathrm{km}$ & -0.4 & -1.8 & -1.4 & -1.9 & -1.8 & -1.5 \\
\hline & 36-km East & -2.6 & -7.1 & -4.8 & -4.9 & -10.8 & -6.0 \\
\hline & 36-km West & -10.0 & 0.6 & -3.8 & -3.6 & -1.4 & -3.6 \\
\hline \multirow{3}{*}{ Spring } & $12-\mathrm{km}$ & 20.2 & 0.5 & 9.3 & 4.9 & 12.8 & 9.5 \\
\hline & 36-km East & 8.9 & -6.8 & -1.6 & -5.6 & 0.8 & -0.9 \\
\hline & 36-km West & 9.7 & -1.7 & 24.2 & 8.7 & 20.8 & 12.3 \\
\hline \multirow{3}{*}{ Summer } & $12-\mathrm{km}$ & 44.8 & 12.3 & 20.2 & 23.9 & 15.0 & 23.2 \\
\hline & 36-km East & 42.2 & 6.2 & 8.4 & 16.3 & 0.4 & 14.7 \\
\hline & 36-km West & 64.3 & 85.3 & 43.9 & 49.5 & 29.7 & 54.5 \\
\hline \multirow{3}{*}{ Fall } & $12-\mathrm{km}$ & -16.9 & -15.5 & -16.1 & -20.7 & -15.4 & -16.9 \\
\hline & 36-km East & -16.6 & -20.0 & -18.4 & -22.1 & -22.2 & -19.9 \\
\hline & 36-km West & -11.6 & 8.2 & -7.8 & 9.5 & 14.2 & 2.5 \\
\hline \multirow{3}{*}{ Annual } & $12-\mathrm{km}$ & 12.9 & -0.1 & 4.1 & 2.4 & 2.4 & 4.3 \\
\hline & 36-km East & 9.0 & -6.0 & -3.5 & -3.2 & -8.4 & -2.4 \\
\hline & 36-km West & 0.5 & 5.7 & 5.8 & 10.7 & 10.9 & 6.7 \\
\hline
\end{tabular}

by linearly adjusting the CMAQ estimated wet deposition by the ratio of the observed to estimated precipitation (see Eq. 1). For example, in the case where the observed precipitation is greater than the model estimated precipitation, the ratio is greater than one, and, therefore, the model estimated wet deposition is increased.

$\frac{\sum_{\text {Seasonal/Annual }} \mathrm{RT}_{\text {Observed }}}{\sum_{\text {Seasonal/Annual }} \mathrm{RT}_{\text {Modeled }}} \times \sum_{\text {Seasonal/Annual }}$ WD $_{\text {Modeled }}$

$=$ Bias Adjusted $\mathrm{WD}_{\text {Modeled }}$

In Eq. (1), "RT" represents the seasonal/annual total accumulated precipitation (either observed or modeled), "WD" represents the seasonal/annual accumulated raw wet deposition estimate from the model, and the "Bias Adjusted WD" is the precipitation bias adjusted seasonal/annual wet deposition estimate from the model.

The precipitation adjustment technique assumes that the observed to modeled precipitation ratio is well correlated with the observed to modeled deposition ratio. In other words, it is not assumed that the wet deposition scales linearly with precipitation, but only that the relationship between the errors in the model precipitation estimates and the error in the CMAQ deposition estimates is linear. Since the bias adjustment was applied over the aggregated seasonal and annual totals, there were no instances in which the observed precipitation was greater than zero while the model estimated precipitation was zero. However, in instances where there is observed precipitation but no model predicted precipitation, the current method of bias adjustment would keep the model estimated wet deposition zero for all species. An analysis of the correlation between the model errors in precipitation and model errors in wet deposition for $\mathrm{SO}_{4}^{=}, \mathrm{NO}_{3}^{-}$and $\mathrm{NH}_{4}^{+}$ for different years, seasons and regions is being documented in a separate manuscript. The precipitation adjustment has been found to be quite effective as an exploratory evaluation tool to help identify compensating errors in deposition predictions from the emissions and meteorological input data. The impact of the precipitation bias adjustment on model performance will be presented for each of the wet deposition species.

\section{Assessment of CMAQ wet deposition performance}

In order to provide a comprehensive assessment of the CMAQ wet deposition estimates, several different types of analyses will be presented. The performance of the model estimates are assessed on several time scales, including monthly, seasonally, annually and finally a multi-annual assessment of model performance. The performance for the 36-km and 12-km CMAQ simulations will be compared to examine how similar or dissimilar the model estimates are for a given time period. Since the 12-km CMAQ domain only covers the eastern two-thirds of the US, comparison to the 36-km results will be limited to the same geographic region (herein referred to as 36-km East). Results for the western one-third of the US will be limited to estimates from the 36-km CMAQ simulation (herein referred to as $36-\mathrm{km}$ West) only, since no 12-km model data are available for the western US for the current analysis. The model estimates will also be examined spatially to identify regional biases. 


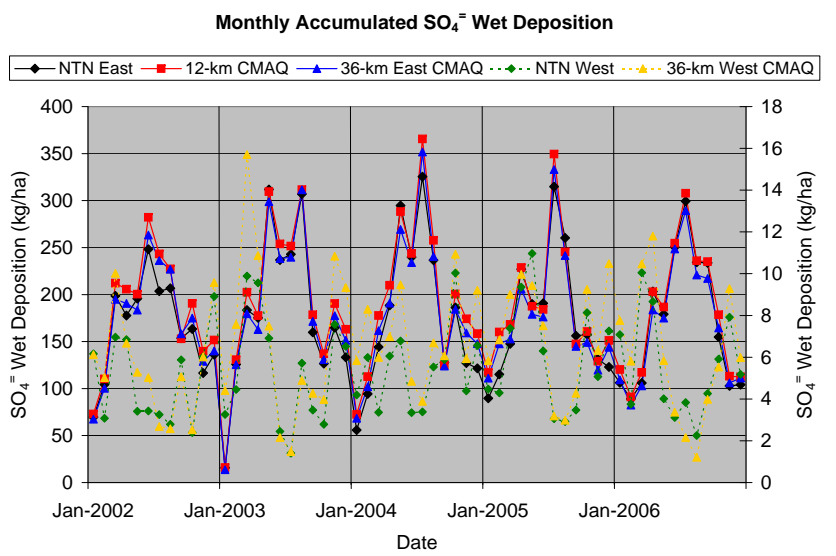

Fig. 1. Monthly accumulated (across all sites) $\mathrm{SO}_{4}^{=}$wet deposition $\left(\mathrm{kg} \mathrm{ha}^{-1}\right)$ for the eastern US NTN observations (black diamonds), 12-km CMAQ simulation (red squares), 36-km East CMAQ simulation (blue triangles), western US NTN observations (dashed; green diamonds) and 36-km West CMAQ (dashed; yellow triangles). The scale for the western US values is given on the right $y$-axis.

\subsection{Precipitation}

Simulated precipitation is a critical driver in the performance of the CMAQ simulated wet deposition estimates, especially since large biases in model estimated precipitation can translate into biases in the CMAQ model estimates. Table 1 presents the seasonal and annual normalized mean bias (NMB) for precipitation for the 12-km, 36-km East and 36$\mathrm{km}$ West domains for the five years simulated (RMSE values can be found in similar tables in the supplement). For the eastern US, the precipitation bias and error are lowest in the winter (December, January and February) and spring (March, April and May) seasons, when the majority of the precipitation is on the synoptic scale (i.e. large-scale frontal systems) and can generally be well resolved by the model. In the summer (June, July and August) and early fall (September, October and November) a large amount of the precipitation is sub-grid scale convective rain, which meteorological models tend to have difficultly representing accurately through the various parameterizations, which results in higher precipitation biases in those seasons. See Fig. S1 in the supplement for spatial plots of the NTN observed and MM5 estimated annual precipitation (12-km simulation only).

While the precipitation estimates for the $12-\mathrm{km}$ and $36-$ $\mathrm{km}$ East simulations have similar patterns in their bias, the precipitation estimates for the $12-\mathrm{km}$ simulation are consistently higher than those of the $36-\mathrm{km}$ East simulation. This results in a slightly larger bias in the winter, spring and summer and a slightly smaller bias in the fall for the $12-\mathrm{km}$ simulation. The bias and error in precipitation tend to be larger for the western US than for the eastern US, which is especially evident in the summer, when precipitation is grossly

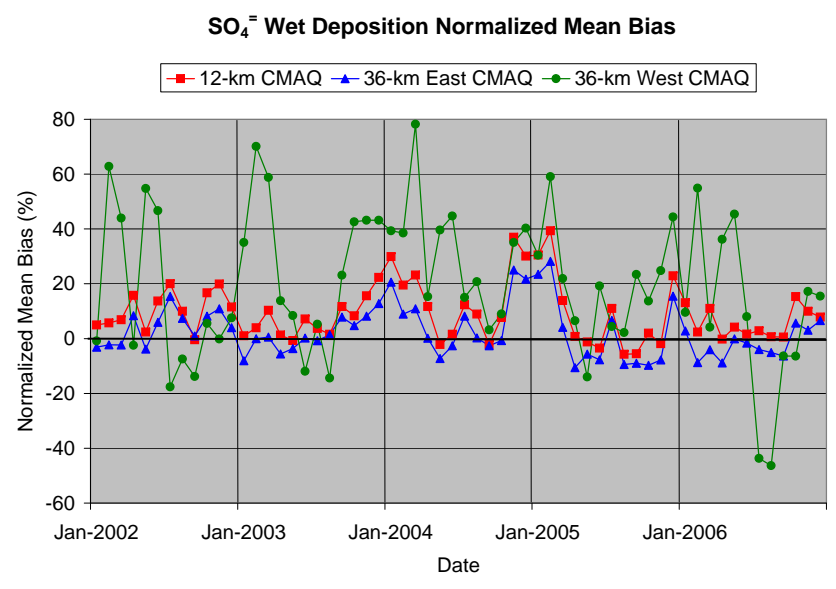

Fig. 2. $\mathrm{SO}_{4}^{=}$wet deposition $\mathrm{NMB}$ for the 12-km CMAQ simulation (red squares), 36-km East CMAQ simulation (blue triangles) and the 36-km West CMAQ simulation (green circles).

overestimated in the 36-km West simulation (summer average $\mathrm{NMB}=54.5 \%$ for the five-year period). Seasonally, precipitation for the eastern US is overestimated in the summer and underestimated in the fall, and relatively unbiased in the winter and spring, while for the western US precipitation is overestimated in the spring and summer and relatively unbiased in the winter and fall. Across the five-year period, the annual NMB for precipitation for the 12-km simulation was typically less than $5 \%$ (the exception being 2002 when the bias was significantly higher). The annual NMB for the $36-\mathrm{km}$ simulations tended to be slightly larger than $12-\mathrm{km}$ simulation. Overall for the entire five-year period precipitation is slightly overestimated in the $12-\mathrm{km}$ and $36-\mathrm{km}$ West simulations and slightly underestimated in the $36-\mathrm{km}$ East simulation.

\section{2 $\mathrm{SO}_{4}^{=}$wet deposition}

Model estimates from both the $12-\mathrm{km}$ and $36-\mathrm{km}$ simulations capture the seasonal trends in the observed monthly accumulated $\mathrm{SO}_{4}^{=}$wet deposition for the 2002-2006 period, with the estimates from the 12-km CMAQ simulation consistently higher than those from the 36-km East simulation (Fig. 1). The CMAQ model on average overestimates $\mathrm{SO}_{4}^{=}$wet deposition in the eastern US However, $88 \%$ of the model estimates from the $36-\mathrm{km}$ East simulation and $80 \%$ of the estimates from the $12-\mathrm{km}$ simulation have a NMB of less than $\pm 15 \%$ (Fig. 2). The largest overestimations of $\mathrm{SO}_{4}^{=}$wet deposition occur in the late fall and winter, generally between October and March.

The bias in $\mathrm{SO}_{4}^{=}$wet deposition estimates for the eastern US was relatively small for both the $12-\mathrm{km}$ and $36-\mathrm{km}$ East simulations (Table 2). The bias is highest in the winter, with the annual NMB values ranging from $8.1 \%$ to $30.7 \%$, and a five-year average NMB of $17.2 \%$ for the $12-\mathrm{km}$ simulation. 
Table 2. Seasonal and annual NMB (\%) for $\mathrm{SO}_{4}^{=}$wet deposition for the 12-km and 36-km CMAQ model simulations.

\begin{tabular}{|c|c|c|c|c|c|c|c|}
\hline & CMAQ Domain & 2002 & 2003 & 2004 & 2005 & 2006 & $\begin{array}{r}\text { Five-Year } \\
\text { Average }\end{array}$ \\
\hline \multirow{3}{*}{ Winter } & $12-\mathrm{km}$ & 8.1 & 12.7 & 26.4 & 30.7 & 8.1 & 17.2 \\
\hline & 36-km East & -0.8 & 5.2 & 16.3 & 23.1 & 1.0 & 9.0 \\
\hline & 36-km West & 14.1 & 49.7 & 39.4 & 32.5 & 22.1 & 31.6 \\
\hline \multirow{3}{*}{ Spring } & $12-\mathrm{km}$ & 8.1 & 2.8 & 7.8 & 3.5 & 3.8 & 5.2 \\
\hline & 36-km East & -0.6 & -4.5 & -1.3 & -5.3 & -5.8 & -3.5 \\
\hline & 36-km West & 27.7 & 29.3 & 38.5 & 2.5 & 23.6 & 24.3 \\
\hline \multirow{3}{*}{ Summer } & $12-\mathrm{km}$ & 14.5 & 3.9 & 8.1 & 1.7 & 2.1 & 6.1 \\
\hline & 36-km East & 9.3 & 0.0 & 2.6 & -2.4 & -3.6 & 1.2 \\
\hline & 36-km West & 8.7 & -9.8 & 25.8 & 11.5 & -26.8 & 1.9 \\
\hline \multirow{3}{*}{ Fall } & $12-\mathrm{km}$ & 11.5 & 12.2 & 13.3 & -1.8 & 7.2 & 8.5 \\
\hline & 36-km East & 5.9 & 5.9 & 5.1 & -7.9 & -1.4 & 1.4 \\
\hline & 36-km West & -4.8 & 38.0 & 13.0 & 19.1 & 4.0 & 13.9 \\
\hline \multirow{3}{*}{ Annual } & $12-\mathrm{km}$ & 11.0 & 6.4 & 11.4 & 6.0 & 4.6 & 7.9 \\
\hline & 36-km East & 4.2 & 0.5 & 3.7 & -1.5 & -3.0 & 0.8 \\
\hline & 36-km West & 12.6 & 29.9 & 28.4 & 13.0 & 10.8 & 18.9 \\
\hline
\end{tabular}

The bias for the 36-km East simulation was on average about $8 \%$ smaller than for the $12-\mathrm{km}$ simulation. The bias is smallest in the summer, with annual NMB values ranging from $1.7 \%$ to $14.5 \%$ and a five-year average NMB of $5.2 \%$ for the $12-\mathrm{km}$ simulation. As was the case in the winter, the bias is slightly smaller for the $36-\mathrm{km}$ East simulation. Bias in the spring and fall periods generally falls between the performance for the summer and winter.

Sulfate wet deposition in the western US is much lower than the eastern US (Fig. 1). This is primarily due to few large $\mathrm{SO}_{2}$ sources in the western US, while the eastern US has a large number of coal fired power plants that emit large amounts of $\mathrm{SO}_{2}$. The $\mathrm{SO}_{4}^{=}$wet deposition performance for the western US is considerably worse than for the eastern US, with the NMB exceeding $40 \%$ in 18 of the 60 months (Fig. 2). This result is not surprising given the challenging meteorological (recall the large precipitation biases in the western US) and air quality conditions that exist in the western US due to its complex topography. Also note that $\mathrm{SO}_{4}^{=}$ wet deposition in the western US is an order of magnitude less than that in the eastern US (Fig. 1), which may also contribute to the larger normalized bias. As was the case for the eastern US, the poorest model performance for the western US was in the winter, which had an average NMB of $31.6 \%$ for the five-year period, while the summer had the lowest bias, with a five-year average NMB of just $1.9 \%$. The NMB was slightly higher in the spring $(24.3 \%)$ than the fall $(13.9 \%)$. For the entire five-year period the average NMB for the $36-\mathrm{km}$ West simulation was $18.9 \%$. Given the complexity of the terrain over much of the western US, a simulation utilizing finer grid spacing (e.g. 12-km) may result in improved performance, as some of the finer details of the topography would be captured in the modeling system.

Spatially, annual $\mathrm{SO}_{4}^{=}$wet deposition is highest in the eastern half of the US where the largest $\mathrm{SO}_{2}$ emissions occur (see Fig. S2, supplement). The highest amounts of $\mathrm{SO}_{4}^{=}$wet deposition occur in the Ohio Valley and Great Lakes regions, and stretching into parts of the Northeast. While these spatial features are well captured by the CMAQ model for all five years, the model tends to overestimate annual $\mathrm{SO}_{4}^{=}$wet deposition in the Ohio Valley region, with some model estimates exceeding $27 \mathrm{~kg} \mathrm{ha}^{-1}$ in areas where observations indicate annual $\mathrm{SO}_{4}^{=}$wet deposition of $19-20 \mathrm{~kg} \mathrm{ha}^{-1}$. The model also underestimates the $\mathrm{SO}_{4}^{=}$wet deposition along parts of the coast of the Gulf of Mexico, although to varying degrees throughout the five-year period. Overall the model captures the spatial variations in annual $\mathrm{SO}_{4}^{=}$wet deposition.

\section{3 $\mathrm{NH}_{4}^{+}$wet deposition}

The pattern of $\mathrm{NH}_{4}^{+}$wet deposition closely follows the seasonal $\mathrm{SO}_{4}^{=}$wet deposition pattern, with a peak in $\mathrm{NH}_{4}^{+}$wet deposition in the eastern US in the summer and a minimum in the winter (Fig. 3). Also similar to $\mathrm{SO}_{4}^{=}$wet deposition, the $\mathrm{NH}_{4}^{+}$wet deposition bias for the eastern US is largest in the summer. However, unlike the $\mathrm{SO}_{4}^{=}$wet deposition, the peak underprediction in $\mathrm{NH}_{4}^{+}$wet deposition in the eastern US typically occurs in late spring and early summer (April - June), whereas the underestimation in $\mathrm{SO}_{4}^{=}$wet deposition typically peaks in the mid to late summer period. For the western US, $\mathrm{NH}_{4}^{+}$wet deposition is more often underestimated than overestimated (Fig. 3), however there are several 
Table 3. Seasonal and annual NMB (\%) for $\mathrm{NH}_{4}^{+}$wet deposition for the 12-km and 36-km CMAQ model simulations.

\begin{tabular}{|c|c|c|c|c|c|c|c|}
\hline & CMAQ Domain & 2002 & 2003 & 2004 & 2005 & 2006 & $\begin{array}{r}\text { Five-Year } \\
\text { Average }\end{array}$ \\
\hline \multirow{3}{*}{ Winter } & $12-\mathrm{km}$ & -19.4 & -18.3 & -13.3 & 2.0 & -18.9 & -13.6 \\
\hline & 36-km East & -23.5 & -25.0 & -18.9 & 1.5 & -21.7 & -17.5 \\
\hline & 36-km West & -39.0 & -41.5 & -35.6 & -42.2 & -27.2 & -37.1 \\
\hline \multirow{3}{*}{ Spring } & $12-\mathrm{km}$ & -13.5 & -28.1 & -17.7 & -20.0 & -20.4 & -19.9 \\
\hline & 36-km East & -16.8 & -30.5 & -22.1 & -24.5 & -23.9 & -23.6 \\
\hline & 36-km West & -2.5 & -19.7 & 0.8 & -5.2 & 9.4 & -3.4 \\
\hline \multirow{3}{*}{ Summer } & $12-\mathrm{km}$ & -7.8 & -8.6 & -2.2 & -7.8 & -10.4 & -7.4 \\
\hline & 36-km East & -8.0 & -8.0 & -2.2 & -8.3 & -11.9 & -7.7 \\
\hline & 36-km West & -19.3 & -43.4 & 10.3 & 0.3 & -41.4 & -18.7 \\
\hline \multirow{3}{*}{ Fall } & $12-\mathrm{km}$ & -8.6 & -3.5 & -6.5 & -20.5 & -8.5 & -9.5 \\
\hline & 36-km East & -11.9 & -6.2 & -9.7 & -20.6 & -11.8 & -12.0 \\
\hline & 36-km West & -42.3 & 14.6 & -9.4 & 23.0 & -22.7 & -7.4 \\
\hline \multirow{3}{*}{ Annual } & $12-\mathrm{km}$ & -11.2 & -16.0 & -9.8 & -13.2 & -14.0 & -12.8 \\
\hline & 36-km East & -13.4 & -17.9 & -12.5 & -15.5 & -16.6 & -15.2 \\
\hline & 36-km West & -25.0 & -23.5 & -9.6 & -5.4 & -15.2 & -15.7 \\
\hline
\end{tabular}

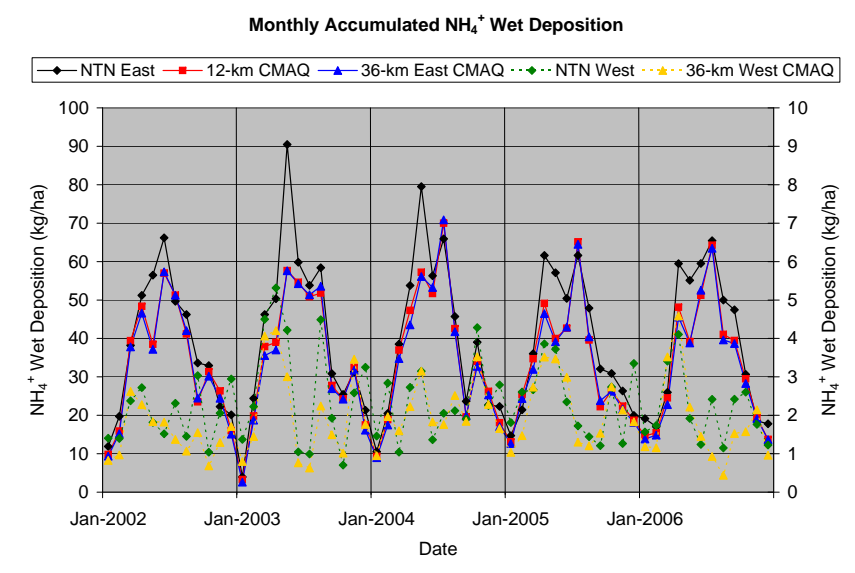

Fig. 3. Monthly accumulated (across all sites) $\mathrm{NH}_{4}^{+}$wet deposition $\left(\mathrm{kg} \mathrm{ha}^{-1}\right)$ for the eastern US NTN observations (black diamonds), 12-km CMAQ simulation (red squares), 36-km East CMAQ simulation (blue triangles), western US NTN observations (dashed; green diamonds) and 36-km West CMAQ (dashed; yellow triangles). The scale for the western US values is given on the right y-axis.

months, particularly in the spring and fall seasons, when large biases occur (Fig. 4).

The largest bias in $\mathrm{NH}_{4}^{+}$wet deposition for the eastern US occurs in the spring, with five-year average NMBs of $-19.9 \%$ and $-23.6 \%$ for the $12-\mathrm{km}$ and $36-\mathrm{km}$ East CMAQ simulations respectively (Table 3 ). Conversely, the spring season has the smallest bias for the western US, with an average NMB of just $-3.4 \%$. The winter has a relatively large bias for both the eastern and western domains, with average

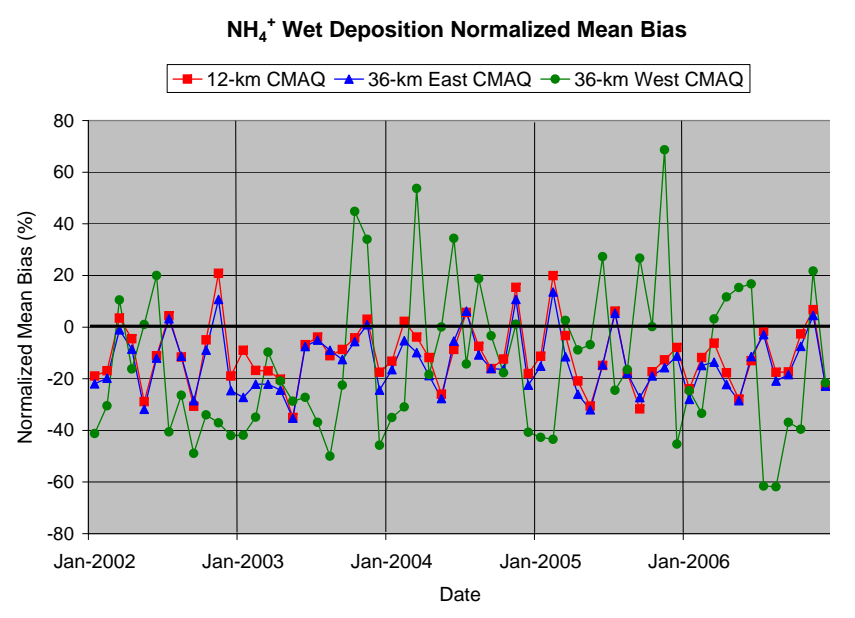

Fig. 4. $\mathrm{NH}_{4}^{+}$wet deposition NMB for the 12-km CMAQ simulation (red squares), 36-km East CMAQ simulation (blue triangles) and the 36-km West CMAQ simulation (green circles).

NMBs of $-13.6 \%$ and $-17.5 \%$ for the $12-\mathrm{km}$ and $36-\mathrm{km}$ East simulations, respectively, and $-37.1 \%$ for the western US The NMB for the summer and fall periods is similar for the eastern US and generally ranges between $-2.0 \%$ to $-20.0 \%$ across the five years. Overall for the five-year period $\mathrm{NH}_{4}^{+}$wet deposition is underestimated, with the fiveyear average NMB ranging from $-12.8 \%$ to $-15.7 \%$ for the three simulations.

Spatially, the highest observed annual $\mathrm{NH}_{4}^{+}$wet deposition occurs in the mid-Atlantic, Great Lakes, Mid-West and portions of Northeast (Fig. S3, supplement). While the CMAQ 
Table 4. Seasonal and annual NMB (\%) for $\mathrm{NO}_{3}^{-}$wet deposition for the 12-km and 36-km CMAQ model simulations.

\begin{tabular}{rrrrrrrr}
\hline & CMAQ Domain & 2002 & 2003 & 2004 & 2005 & 2006 & $\begin{array}{r}\text { Five-Year } \\
\text { Average }\end{array}$ \\
\hline \multirow{3}{*}{ Winter } & $12-\mathrm{km}$ & 12.3 & 10.1 & 16.9 & 20.6 & 8.8 & 13.7 \\
& 36-km East & 3.9 & 0.5 & 7.4 & 12.0 & 1.8 & 5.1 \\
& $36-\mathrm{km}$ West & 5.8 & 21.6 & 24.9 & 11.2 & 17.2 & 16.1 \\
\hline \multirow{4}{*}{ Spring } & $12-\mathrm{km}$ & -8.7 & -13.3 & -15.3 & -15.6 & -19.7 & -14.5 \\
& $36-\mathrm{km}$ East & -16.4 & -20.9 & -23.6 & -24.2 & -28.1 & -22.6 \\
& $36-\mathrm{km}$ West & -7.3 & -2.7 & -6.6 & -1.3 & 18.1 & 0.0 \\
\hline \multirow{3}{*}{ Summer } & $12-\mathrm{km}$ & -38.0 & -39.4 & -38.7 & -39.9 & -45.4 & -40.3 \\
& $36-\mathrm{km}$ East & -40.3 & -41.9 & -43.2 & -43.4 & -49.9 & -43.7 \\
& $36-\mathrm{km}$ West & -49.6 & -62.0 & -36.2 & -26.4 & -63.9 & -47.6 \\
\hline \multirow{3}{*}{ Fall } & $12-\mathrm{km}$ & 3.7 & 2.4 & 11.5 & -9.0 & -1.1 & 1.5 \\
& $36-\mathrm{km}$ East & -3.4 & -4.5 & 3.0 & -14.1 & -9.2 & -5.6 \\
& $36-\mathrm{km}$ West & -29.0 & 16.3 & -6.2 & 9.2 & -16.7 & -5.3 \\
\hline \multirow{3}{*}{ Annual } & $12-\mathrm{km}$ & -12.5 & -15.6 & -12.8 & -14.6 & -19.7 & -15.0 \\
& $36-\mathrm{km}$ East & -18.4 & -21.6 & -20.1 & -23.1 & -26.4 & -21.9 \\
& $36-\mathrm{km}$ West & -18.0 & -6.0 & -4.7 & -1.8 & -7.4 & -7.6 \\
\hline
\end{tabular}

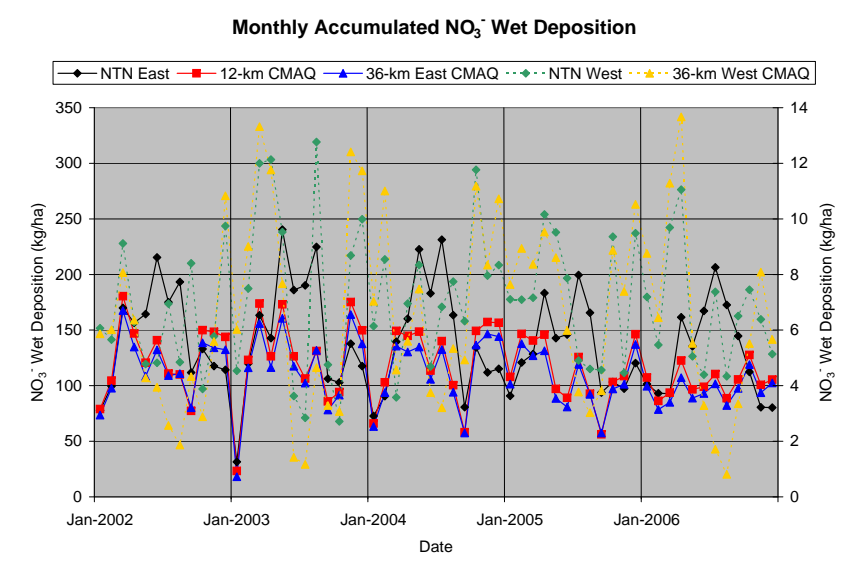

Fig. 5. Monthly accumulated (across all sites) $\mathrm{NO}_{3}^{-}$wet deposition (kg ha-1) for the eastern US NTN observations (black diamonds), 12-km CMAQ simulation (red squares), 36-km East CMAQ simulation (blue triangles), western US NTN observations (dashed; green diamonds) and 36-km West CMAQ (dashed; yellow triangles). The scale for the western US values is given on the right y-axis.

model estimates the highest annual $\mathrm{NH}_{4}^{+}$wet deposition over the Great Lakes and Mid-West regions, the model consistently underestimates the spatial extent of the highest $\mathrm{NH}_{4}^{+}$ wet deposition in those regions (Fig. S5). The model does well estimating the localized peak in annual $\mathrm{NH}_{4}^{+}$wet deposition in eastern North Carolina, where a large number of confined animal feeding operations contribute to a peak in $\mathrm{NH}_{4}^{+}$wet deposition in that area. Overall, the model repro-

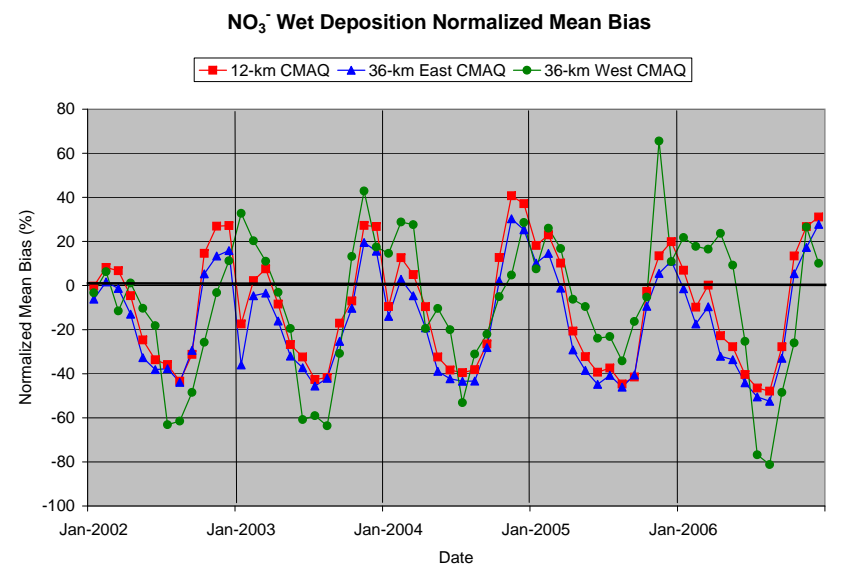

Fig. 6. $\mathrm{NO}_{3}^{-}$wet deposition $\mathrm{NMB}$ for the 12-km CMAQ simulation (red squares), 36-km East CMAQ simulation (blue triangles) and the 36-km West CMAQ simulation (green circles).

duces the pattern of annual $\mathrm{NH}_{4}^{+}$wet deposition each year, but consistently underestimates the magnitude of $\mathrm{NH}_{4}^{+}$wet deposition.

\section{4 $\mathrm{NO}_{3}^{-}$wet deposition}

The $\mathrm{NO}_{3}^{-}$wet deposition performance is dominated by large underestimations in the summer (Fig. 5), which is consistent with the performance of CMAQ model estimates of aerosol fine particulate $\mathrm{NO}_{3}^{-}$(Appel et al., 2008). The CMAQ model estimates of $\mathrm{NO}_{3}^{-}$wet deposition for the fall and winter 
Annual: Modeled - Observed SO4 Wet Deposition

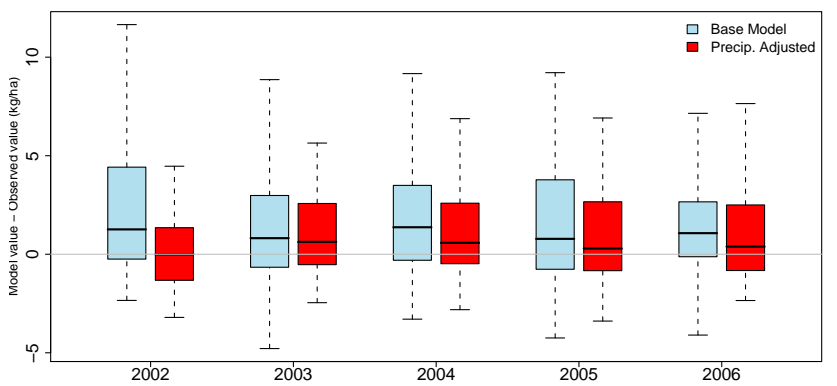

Fig. 7. Box plots of annual modeled - observed $\mathrm{SO}_{4}^{=}$wet deposition for model wet deposition estimates without any adjustment for precipitation bias ("Base Model"; blue) and the for model estimates adjusted for precipitation errors ("Precip. Adjusted"; red). The black line within the box represents the median bias, shading represents the range of the $25 \%$ to $75 \%$ quartile, and the dashed lines represent the range of the $5 \%$ to $95 \%$ values.

seasons are relatively consistent for the eastern US, with the NMB ranging between $\pm 20 \%$ for both the $12-\mathrm{km}$ and 36$\mathrm{km}$ East CMAQ simulations (Fig. 6). In the spring, $\mathrm{NO}_{3}^{-}$ wet deposition is underestimated in the eastern US, with average NMBs of $-14.5 \%$ and $-22.6 \%$ for the $12-\mathrm{km}$ and 36 $\mathrm{km}$ East CMAQ simulations, respectively (Table 4). For the western US the NMB is unbiased in the spring. For the summer, the $\mathrm{NO}_{3}^{-}$wet deposition is largely underestimated for both the eastern and western US, with NMBs greater than $-40 \%$ for all three simulations. It should be noted that $\mathrm{NO}_{3}^{-}$ concentrations are small in the eastern US in the summer. For the entire five-year period the model underestimates $\mathrm{NO}_{3}^{-}$ wet deposition, with a five-year average NMB of $-14.9 \%$ and $-21.4 \%$ for the $12-\mathrm{km}$ and $36-\mathrm{km}$ East simulations, respectively, and a NMB of $-6.9 \%$ for the $36-\mathrm{km}$ West simulation.

There is a clear downward trend in the NTN observations of $\mathrm{NO}_{3}^{-}$wet deposition from 2002-2006, which is also seen in the CMAQ model estimates (Fig. 5). The trend toward lower $\mathrm{NO}_{3}^{-}$wet deposition may be due at least in part to the implementation of rules under the $\mathrm{NO}_{\mathrm{x}}$ SIP Call (http://www.epa.gov/ttn/naaqs/ozone/rto/sip/index. html) in mid 2003, which greatly reduced the amount of $\mathrm{NO}_{\mathrm{x}}$ emissions in 22 states in the eastern US While the CMAQ model generally does well reproducing the overall observed spatial pattern of $\mathrm{NO}_{3}^{-}$wet deposition, the model consistently underestimates the $\mathrm{NO}_{3}^{-}$wet deposition in parts of the Northeast and Great Lakes regions, specifically New York, eastern Pennsylvania and Michigan, while overestimating the deposition in western Pennsylvania and West Virginia (Fig. S4).

\subsection{Corrections impacting wet deposition}

\subsubsection{Precipitation bias correction}

The change in annual $\mathrm{SO}_{4}^{=}$wet deposition model bias as a result of applying the precipitation bias adjustment described in Sect. 2.5 for the 12-km simulation is shown in Fig. 7. At least some improvement in model bias for each of the five years occurs by applying the precipitation bias adjustment. However, the improvement varies significantly from year to year, with the largest improvement in model performance in 2002, where the annual NMB decreases from $21 \%$ to $2 \%$, while for 2003 and 2006 the NMB improves by only $3 \%$ or less. Spatially, the largest precipitation bias typically occurs in the Northeast and Great Lakes regions (particularly in 2002), and those regions show the largest improvement in bias and error as a result of the adjustment for precipitation bias (see Figs. S5 and S6, supplement for regional statistics).

To test the robustness of the precipitation bias adjustment, a bootstrap sampling technique was applied. For each year, the NTN observations were re-sampled with replacement 1000 times. The sample size for each of the 1000 samples matched the number of observations available for that year. The base model $\mathrm{SO}_{4}^{=}$wet deposition estimates and precipitation bias corrected model estimates were matched to these pseudo-sets of observations, and the RMSE for each sample was computed. The bootstrap distribution of RMSE values for the base model results and precipitation bias adjusted results is shown in Fig. 8. The largest decrease in RMSE occurs in 2002, 2004 and 2005, while the decrease in RMSE is much smaller in 2003 and 2006, which confirms that the precipitation bias adjustment significantly improves the model performance in 2002, but provides only a minor improvement in 2003 and 2006. The improvement in model performance gained by applying the precipitation bias adjustment is highly dependent on the performance of meteorological model estimates of precipitation, with greater improvement in model performance when the precipitation estimates are poor (e.g. 2002).

Unlike for $\mathrm{SO}_{4}^{=}$wet deposition, applying the precipitation adjustment to the CMAQ estimated $\mathrm{NH}_{4}^{+}$wet deposition generally results in an increase in bias (Fig. 9) and a slight increase in error (Fig. 10) for each of the five years. The increase in bias is largest in 2002, where the NMB increases from $-3 \%$ to $-19 \%$, while for the other years the increase in bias is smaller, generally ranging from $3 \%$ to $7 \%$ (Fig. S7). This suggests that the overestimation in model estimated precipitation is at least partially compensating for an underestimation in $\mathrm{NH}_{4}^{+}$wet deposition. It is important to note that the $\mathrm{NH}_{3}$ emissions used in the CMAQ model simulation are constrained using the results of inverse modeling, so some increase in $\mathrm{NH}_{4}^{+}$wet deposition bias is expected when the model estimates are adjusted for precipitation bias.

Similar to $\mathrm{NH}_{4}^{+}$wet deposition, applying the precipitation bias adjustment to the $\mathrm{NO}_{3}^{-}$wet deposition model estimates 

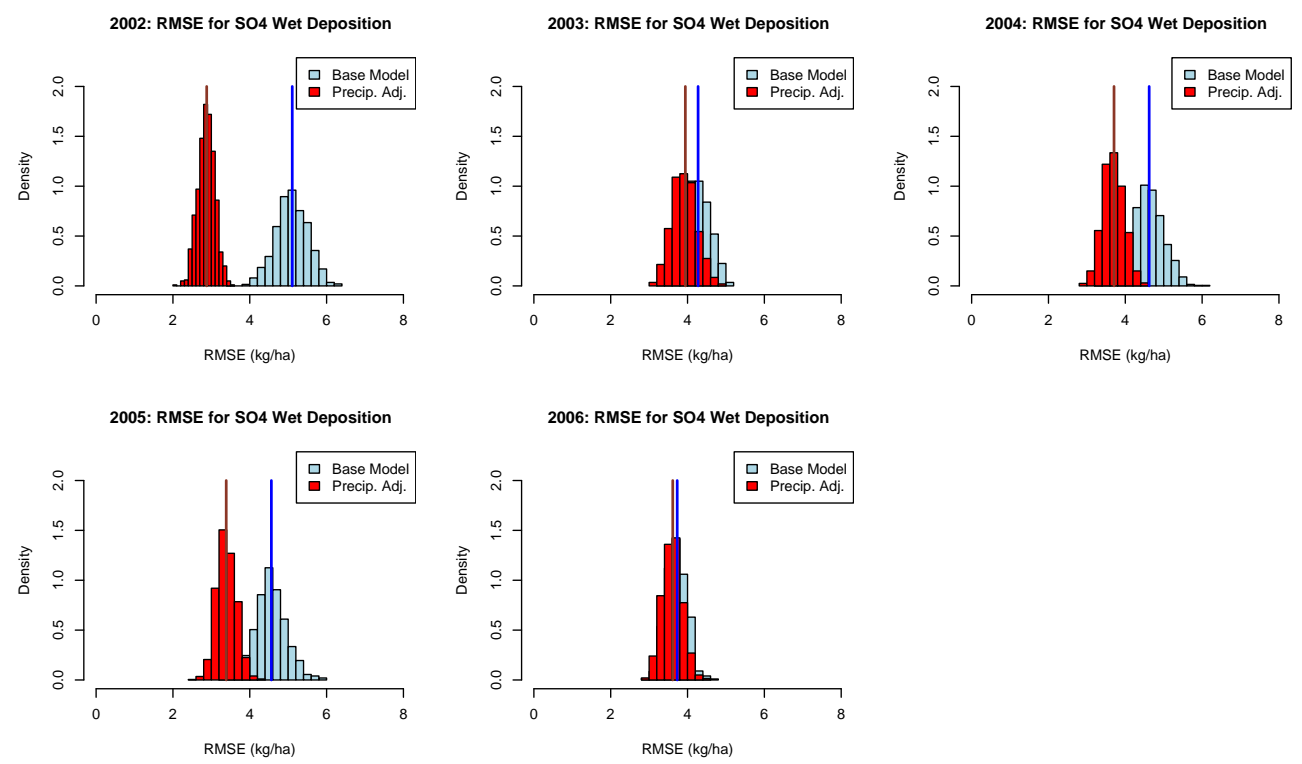

Fig. 8. Distribution of $\mathrm{SO}_{4}^{=}$wet deposition RMSE for model and observation values re-sampled 1000 times. Model estimates without any adjustment for precipitation bias ("Base Model"; blue) and the for model estimates adjusted for precipitation errors ("Precip. Adj."; red). The bold lines indicate the mean RMSE for each distribution.

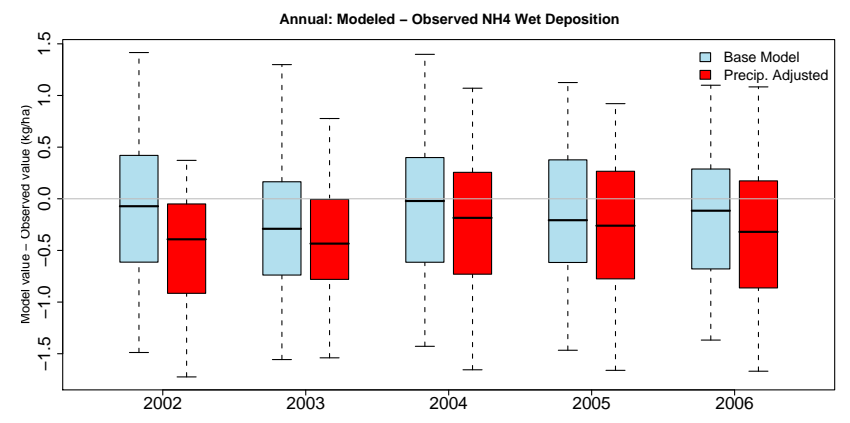

Fig. 9. Box plots of annual modeled - observed $\mathrm{NH}_{4}^{+}$wet deposition for model wet deposition estimates without any adjustment for precipitation bias (blue) and the for model estimates adjusted for precipitation errors (red). The black line within the box represents the median bias, shading represents the range of the $25 \%$ to $75 \%$ quartile, and the dashed lines represent the range of the $5 \%$ to $95 \%$ values.

generally results in an increase in bias (Fig. 11) and either a slight increase or decrease in error for each of the five years (Figs. 12 and S8). One of the large sources contributing to the underestimation of $\mathrm{NO}_{3}^{-}$wet deposition is a lack of lightning generated NO. Lightning can be a large source of upper tropospheric NO, especially in the summer when lightning activity is high, and can contribute significantly to $\mathrm{NO}_{3}^{-}$wet deposition (Fang et al., 2010). The lack of NO produced from lightning is less of a problem in the western US, as lightning activity is generally much lower west of the Rocky Mountains as compared to the eastern US In the base simulations performed here, no lightning generated NO emissions were included in the emissions inventory. In order to estimate the impact of lightning generated $\mathrm{NO}$ on $\mathrm{NO}_{3}^{-}$wet deposition, this source was added to the CMAQ model simulation using the process described in Sect. 3.5.3.

\subsubsection{Bi-Directional $\mathrm{NH}_{3}$ exchange}

The underestimation in $\mathrm{NH}_{4}^{+}$wet deposition may be due in large part to the poor temporal and spatial representation of $\mathrm{NH}_{3}$ emissions, particularly those emissions associated with fertilizer applications and bi-directional exchange of $\mathrm{NH}_{3}$ from soil and vegetation surfaces. In order to improve the $\mathrm{NH}_{3}$ emissions, a bi-directional $\mathrm{NH}_{3}$ exchange mechanism was developed for the CMAQ model which was in turn coupled with an agricultural management tool and a soil nitrogen geochemical cycling model to estimate $\mathrm{NH}_{3}$ emissions from fertilized croplands (Cooter et al., 2010). The agricultural management tool estimates fertilizer application as a function of crop nutrient demand and the soil geochemical model was used to estimate the nitrification and denitrification processes in the soil column and provided the soil water solution ammonium and hydrogen ion concentrations needed in the bi-directional $\mathrm{NH}_{3}$ model. Agricultural land use categories and crop profiles were provided by the US Department of Agriculture's 2002 Census of Agriculture (2002 Census of Agriculture, 2004). A slightly more detailed description of the bi-directional exchange mechanism is provided in the supplementary material, while a much more detailed description of the mechanism will be available in a future publication focused entirely on the mechanism.

To evaluate the impact that bi-directional $\mathrm{NH}_{3}$ exchange has on the CMAQ estimated $\mathrm{NH}_{4}^{+}$wet deposition, a 2002 

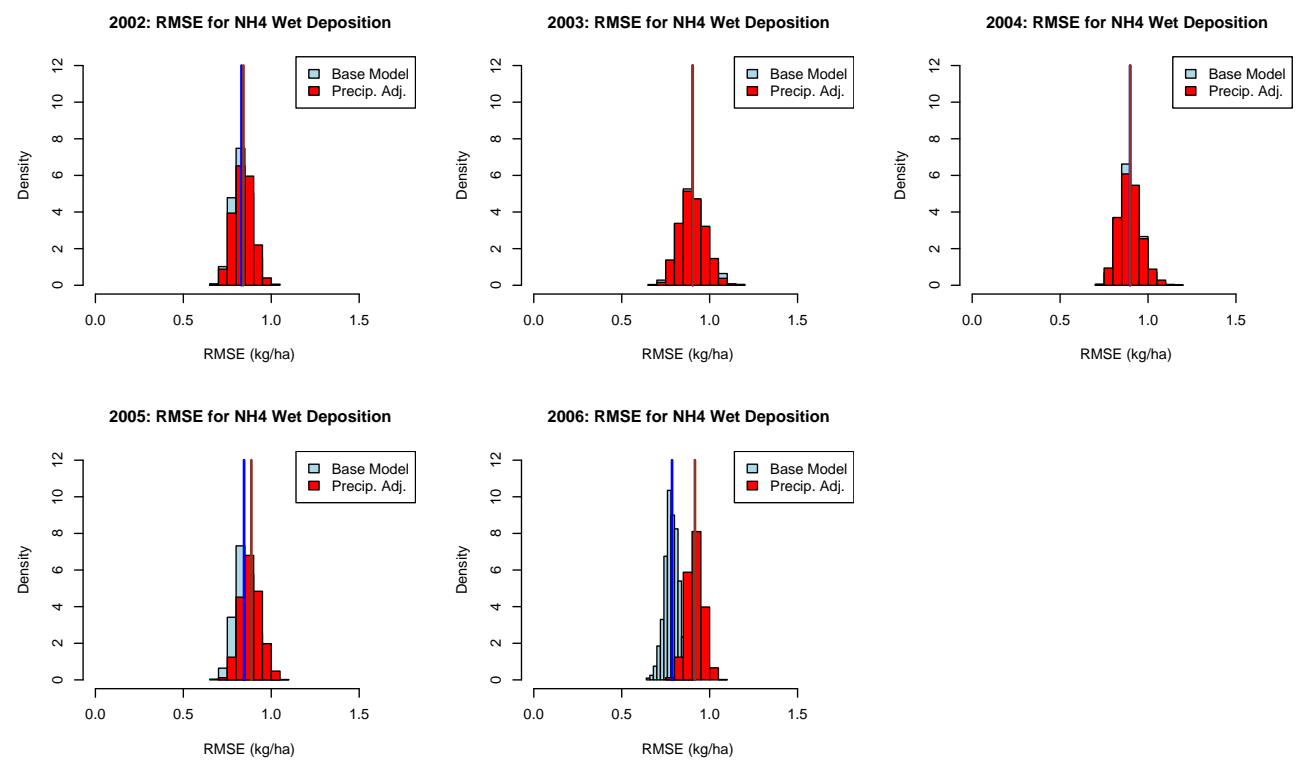

Fig. 10. Distribution of RMSE based on 1000 bootstrap samples of the modeled and observed $\mathrm{NH}_{4}^{+}$wet deposition. Results for model estimates without any adjustment for precipitation bias ("Base Model") are shown in blue and for model estimates adjusted for precipitation errors ("Precip. Adj.") are red. The bold lines indicate the RMSE values from the original dataset.

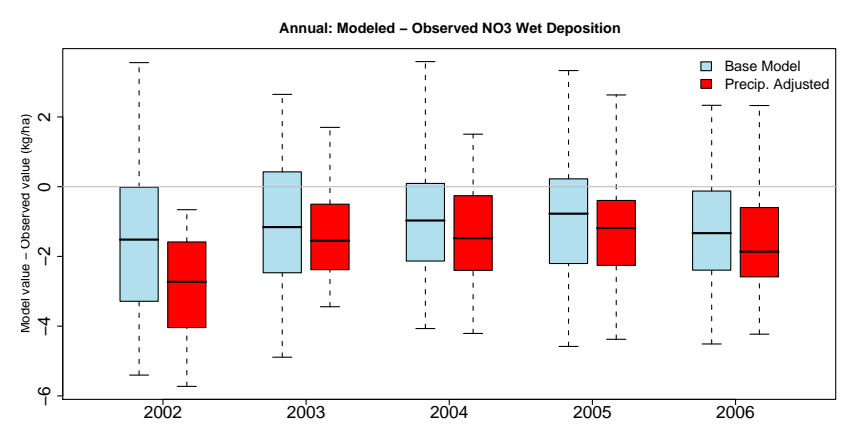

Fig. 11. Box plots of annual modeled - observed $\mathrm{NO}_{3}^{-}$wet deposition for model wet deposition estimates without any adjustment for precipitation bias (blue) and the for model estimates adjusted for precipitation errors (red). The black line within the box represents the median bias, shading represents the range of the $25 \%$ to $75 \%$ quartile, and the dashed lines represent the range of the $5 \%$ to $95 \%$ values.

12-km eastern US CMAQ simulation that included bidirectional exchange was performed, and the results were corrected for precipitation bias (Fig. 13). Including the bidirectional exchange significantly reduces the bias in the precipitation corrected annual $\mathrm{NH}_{4}^{+}$wet deposition, with the NMB reduced by more than a factor of three (from $-19 \%$ to $-6 \%)$. The reduction in the model bias was due to improving the temporal resolution of $\mathrm{NH}_{3}$ emissions from a monthly profile to an hourly profile, representing grid cell level spatial variability instead of county level, and modeling the soil nitrification, de-nitrification, vegetative uptake, and soil evasion of $\mathrm{NH}_{3}$ following fertilizer application rather than using state level fertilizer sales as a surrogate for emissions. Note that annual total $\mathrm{NO}_{3}^{-}$wet deposition changes little $(<1 \%)$ when bi-directional $\mathrm{NH}_{3}$ exchange is implemented due to offsetting increases in $\mathrm{NO}_{3}^{-}$wet deposition in the spring and summertime $(\sim 2 \%)$ and correspondingly large decreases in $\mathrm{NO}_{3}^{-}$wet deposition in the fall and winter. It is anticipated that a beta version of the bi-directional $\mathrm{NH}_{3}$ exchange will be available for the next version of the CMAQ model.

\subsubsection{Lightning generated NO}

The lightning NO production is calculated using the convective precipitation rate from the meteorological model in order to ensure that the lightning is co-located with clouds, convection, and precipitation. A more complete description is available in Allen et al. (2009), but briefly, first the flash frequency is calculated as a function of the convective precipitation rate. Then, for each grid cell, the flash frequency is normalized such that the monthly sum of the modeled flash counts is equal to the monthly sum of the flashes observed by the National Lightning Detection Network (NLDN). The NLDN cloud-to-ground (CG) flash rates are multiplied by $\mathrm{Z}+1$ to account for the contribution of intra-cloud flashes (IC) to the total flash rate, where $\mathrm{Z}$ is the climatological IC/CG ratio from Boccippio et al. (2001). This method captures the day-to-day variability in flash rates, while retaining an accurate estimate of the monthly total (Allen et al., 2009). For each flash, it is assumed that 500 moles of NO are produced (DeCaria et al., 2005; Ott et al., 2007), which is a reasonable mid-latitude value. The NO is vertically distributed from the surface to the model layer containing the convective cloud 

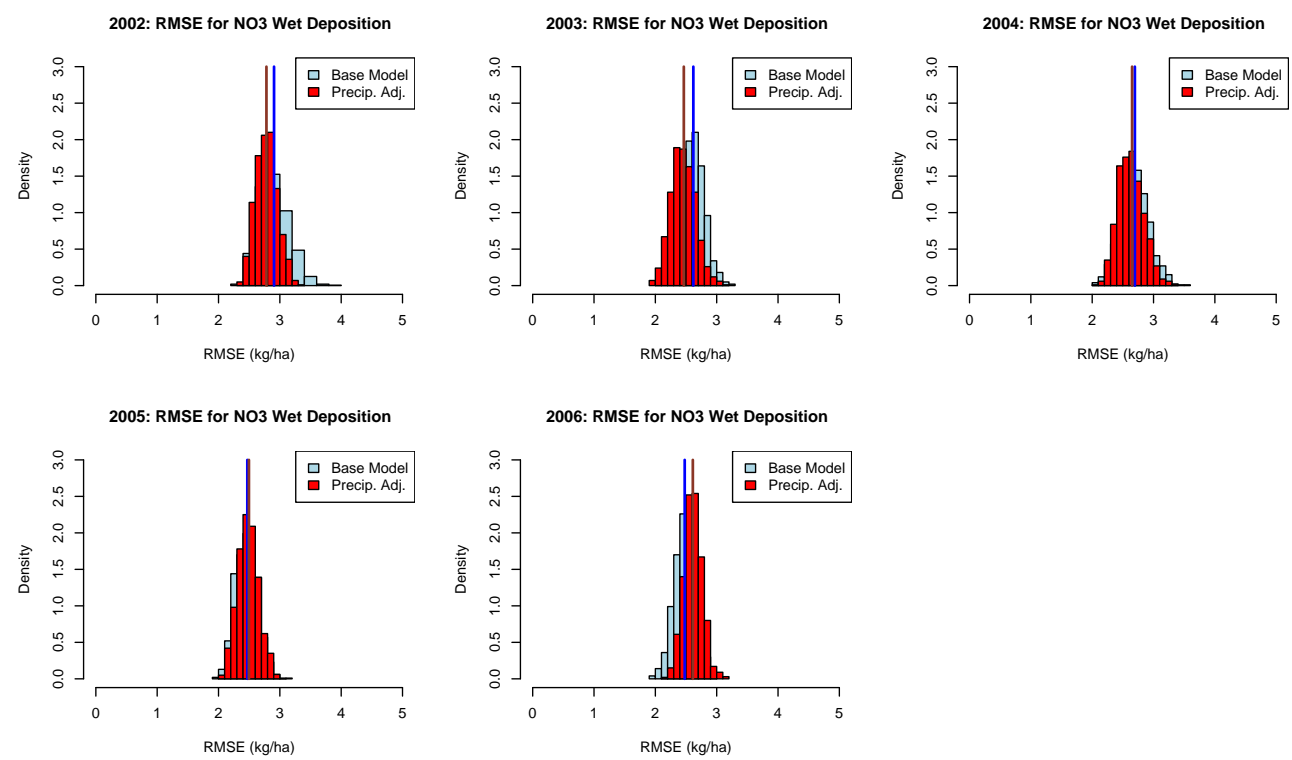

Fig. 12. Distribution of RMSE based on 1000 bootstrap samples of the modeled and observed $\mathrm{NO}_{3}^{-}$wet deposition. Results for model estimates without any adjustment for precipitation bias ("Base Model") are shown in blue and for model estimates adjusted for precipitation errors ("Precip. Adj.") are red. The bold lines indicate the RMSE values from the original dataset.

top using climatological vertical flash rate information from the Northern Alabama Lightning Mapping Array (Koshak et al., 2004).

For the summer of 2004, a CMAQ model simulation using 36-km grid spacing was performed for the CONUS that included lightning produced $\mathrm{NO}$ as described above. Over the entire summer, NO produced from lightning was equal to $30 \%$ of the anthropogenic NO emissions. Because most of the NO produced from lighting is created in the upper troposphere, the impact to surface concentrations is small, as in Kaynak et al. (2008). However, over the eastern US where lightning flash counts are greatest, the impact to $\mathrm{NO}_{3}^{-}$wet deposition is substantial. Figure 14 shows the bias in $\mathrm{NO}_{3}^{-}$ wet deposition at NADP monitoring sites for the CMAQ simulation without lightning NO, including lightning NO, and including lightning NO and the precipitation bias adjustment. For the monitoring locations east of 100 degrees W longitude, the CMAQ simulation with the lightning NO production has a low bias and captures the range of variability shown at the surface monitors. At the monitors west of 100 degrees $\mathrm{W}$ longitude, the impact is small and the bias persists, owing to the low lightning flash counts in this region. An implementation of the method described above for including lightning generated $\mathrm{NO}$ will be included in the next release of the CMAQ model.

\section{Summary}

The CMAQ modeling system was used to estimate $\mathrm{SO}_{4}^{=}$, $\mathrm{NH}_{4}^{+}$and $\mathrm{NO}_{3}^{-}$wet deposition for the years 2002-2006 for the CONUS using a 36-km grid spacing and the eastern US using a $12-\mathrm{km}$ grid spacing. The resulting wet deposition estimates from the model were compared with surface based observations of wet deposition species available across the US from the NTN for the five-year period. For $\mathrm{SO}_{4}^{=}$wet deposition, the operational performance of the CMAQ model estimates were generally comparable for the $36-\mathrm{km}$ and $12-$ $\mathrm{km}$ simulations for the eastern US, with the 12-km simulation on average yielding slightly higher estimates of $\mathrm{SO}_{4}^{=}$wet deposition than the 36-km simulation. When compared to observations from the NTN, the NMB for the CMAQ model estimates was slightly higher for the 12-km simulation; however both simulations had annual NMBs that were less than $\pm 15 \%$ each year. Bias and error in the model $\mathrm{SO}_{4}^{=}$wet deposition estimates were significantly reduced for three of the five years (smaller improvements for the other two years) when the estimates were adjusted to account for biases in the model estimated precipitation.

The CMAQ modeling system underestimates $\mathrm{NH}_{4}^{+}$wet deposition in the eastern US in both the $36-\mathrm{km}$ and $12-\mathrm{km}$ simulations, with the underestimation tending to be slightly larger in the $36-\mathrm{km}$ simulation. The largest underestimation of $\mathrm{NH}_{4}^{+}$wet deposition occurs in the winter and spring periods, while the summer and fall have slightly lower underestimations. The underestimation is likely due in part to the poor temporal and spatial representation of $\mathrm{NH}_{3}$ emissions, particularly those emissions associated with fertilizer applications and bi-directional exchange of $\mathrm{NH}_{3}$ flux from the soil and vegetation. Implementation of a bi-directional $\mathrm{NH}_{3}$ flux mechanism in the CMAQ model, along with improvements 


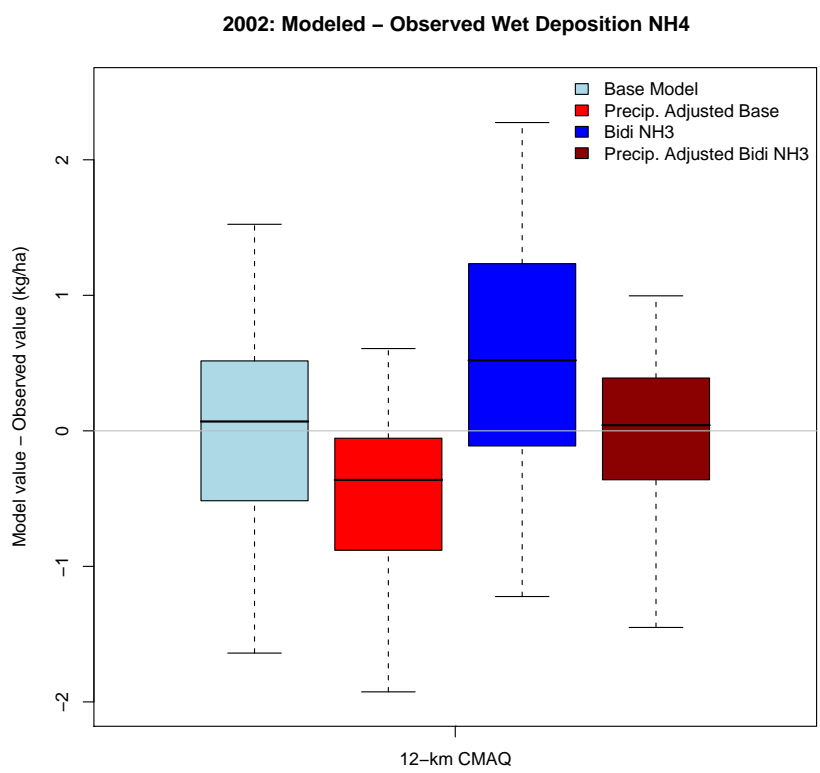

Fig. 13. Box plots of modeled - observed $\mathrm{NH}_{4}^{+}$wet deposition for the eastern US (12-km CMAQ simulation only) for 2002. Shown are the model $\mathrm{NH}_{4}^{+}$wet deposition biases for the base CMAQ simulation ("Base Model"; light blue), the base simulation with precipitation bias adjustment ("Precip. Adjusted Base"; red), the simulation with bi-directional NH3 flux only ("Bidi NH3"; dark blue), and the simulation with both precipitation bias adjusted $\mathrm{NH}_{4}^{+}$wet deposition and bi-directional NH3 flux included ("Precip. Adjusted Bidi $\mathrm{NH}_{3}$ "; dark red).

in the temporal and spatial representation of fertilizer applications, improved the underestimation of $\mathrm{NH}_{4}^{+}$wet deposition, and these changes will likely be included in the next release of the CMAQ model.

The performance for model estimates of $\mathrm{NO}_{3}^{-}$wet deposition is mixed throughout the year, with the model largely underestimating $\mathrm{NO}_{3}^{-}$wet deposition in the spring and summer in the eastern US, while the bias in the fall and winter is relatively small. Model estimates of $\mathrm{NO}_{3}^{-}$wet deposition tend to be slightly lower for the $36-\mathrm{km}$ simulation as compared to the $12-\mathrm{km}$ simulation, particularly in the spring. One large source of the underestimation of $\mathrm{NO}_{3}^{-}$wet deposition is from a lack of $\mathrm{NO}$ produced from lightning in the upper troposphere, which can be a large source of NO, particularly in the summer in the eastern US when lightning activity is high. CMAQ model simulations that include production of NO from lightning show a substantial reduction in the $\mathrm{NO}_{3}^{-}$ wet deposition underestimation in the eastern US in the summer as compared to simulations without lightning NO. There is little impact on bias in the western US when lightning generated NO is included due to the relatively low amount of lightning activity in the western US.

Overall, performance for the $36-\mathrm{km}$ and $12-\mathrm{km}$ CMAQ model simulations was similar for the eastern US, while for the western US the performance of the $36-\mathrm{km}$ simulation

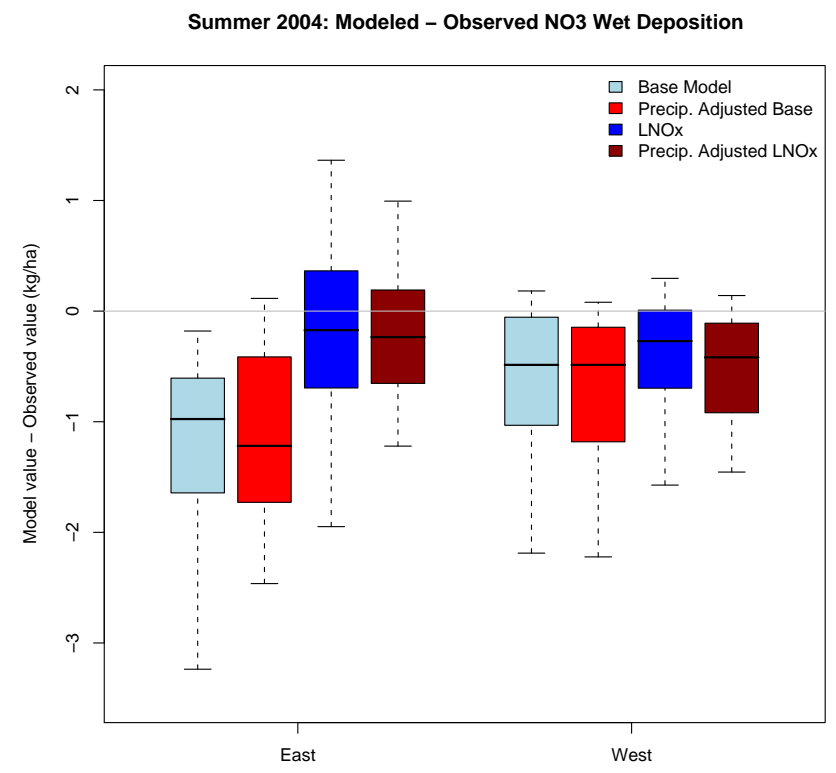

Fig. 14. Box plots of modeled - observed $\mathrm{NO}_{3}^{-}$wet deposition for the eastern (left) and western (right) US for the summer of 2004. Shown are the model $\mathrm{NO}_{3}^{-}$wet deposition biases for the simulation without lightning $\mathrm{NO}_{\mathrm{x}}$ included ("Base Model"; light blue), the simulation with precipitation bias adjustment only ("Precip. Adjusted Base; red), the simulation with lightning $\mathrm{NO}_{\mathrm{x}}$ only included (" $\mathrm{LNO}_{\mathrm{x}}$ "; dark blue), and the simulation with both precipitation bias adjusted $\mathrm{NO}_{3}^{-}$wet deposition and lightning $\mathrm{NO}_{\mathrm{x}}$ included ("Precip. Adjusted $\mathrm{LNO}_{\mathrm{x}}$ "; dark red).

was generally not as good as either eastern US simulation. On an annual basis, the model performance for all three wet deposition species was relatively consistent (NMB <30\%), with mostly small variations in normalized bias (standard deviation $<3 \%$ ) over the five-year period for the eastern US Annual variations in NMB were larger for the western US, with a standard deviation $>5.5 \%$. This suggests that the modeling system does relatively well handling the year-toyear variability in meteorology and emissions that occur over longer periods of time, particularly for the eastern US As annual air quality model simulations become more routine, it is likely that the five-year performance assessment presented here could be extended to cover a longer time-period (e.g. a decade). Additionally, expanding the $12-\mathrm{km}$ simulation to include the western US may result in improved model performance over the 36-km simulation given the complexity of the terrain in the western US.

\section{Supplementary material related to this \\ article is available online at: \\ http://www.geosci-model-dev.net/4/357/2011/ gmd-4-357-2011-supplement.zip.}


Acknowledgements. The authors would like to Lara Reynolds, Nancy Hwang, Lucille Bender and other members of Computer Sciences Corporation for their help in performing the MM5 and CMAQ simulations used in this work. The authors would also like to thank the three anonymous reviewers for their comments and suggestions that greatly improved the quality of the manuscript.

Disclaimer-The United States Environmental Protection Agency through its Office of Research and Development funded and managed the research described here. It has been subjected to Agency review and approved for publication.

Edited by: V. Grewe

\section{References}

Allen, D. J., Pickering, K., Pinder, R. W., and Pierce, T.: Impact of lightning-NO emissions on eastern US photochemistry during the summer of 2004 as determined using the CMAQ model. Presented at the 8th Annual CMAS Conference, Chapel Hill, NC, 19-21 October, 2009.

Appel, K. W., Bhave, P. V., Gilliland, A. B., Sarwar, G., and Roselle, S. J.: Evaluation of the Community Multiscale Air Quality (CMAQ) model version 4.5: Sensitivities impacting model performance; Part II-particulate matter, Atmos. Environ., 42, 6057-6066, 2008.

Appel, K. W., Gilliam, R. C., Davis, N., and Zubrow, A.: Overview of the Atmospheric Model Evaluation Tool (AMET) v1.1 for evaluating meteorological and air quality models, Environ. Modell. Softw., 26, 4, 434-443, 2011.

Bey, I., Jacob, D. J., Yantosca, R. M., Logan, J. A., Field, B. D., Fiore, A. M., Li, Q., Liu, H. Y., Mickley, L. J., and Schultz, M. G.: Global modeling of tropospheric chemistry with assimilated meteorology: Model description and evaluation, J. Geophys. Res., 106, 23073-23096, 2001.

Boccippio, D., Cummings, K., Christian, H., and Goodman, S.: Combined satellite- and surface-based estimation of the intracloud-cloud-to-ground lightning ratio over the continental United States, Mon. Weather. Rev., 129, 108-122, 2001.

Byun, D. W. and Schere, K. L.: Review of the governing equations, computational algorithms, and other components of the Models3 Community Multiscale Air Quality (CMAQ) modeling system, Appl. Mech. Rev., 55, 51-77, 2006.

Carlton, A. G., Bhave, P. V., Napelenok, S. L., Edney, E. O., Sarwar, G., Pinder, R. W., Pouliot, G. A., and Houyoux, M.: Model representation of secondary organic aerosol in CMAQv4.7, Environ. Sci. Technol., 44, 8553-8560, 2010.

Cooter, E., Bash, J. O., Walker, J. T., Jones, M. R., and Robarge, W.: Estimation of $\mathrm{NH}_{3}$ bi-directional flux over managed agricultural soils, Atmos. Environ., 44, 2107-2115, 2010.

Davis, J. M. and Swall, J. L.: An examination of the CMAQ simulations of the wet deposition of ammonium from a Bayesian perspective, Atmos. Environ., 40, 4562-4573, 2006.

DeCaria, A. J., Pickering, K. E., Stenchikov, G. L., and Ott, L. E.: Lightning-generated $\mathrm{NO}_{\mathrm{X}}$ and its impact on tropospheric ozone production: A three-dimensional modeling study of a STERAO-A thunderstorm, J. Geophys. Res., 110, D14303, doi:10.1029/2004JD005556, 2005.
Driscoll, C. T., Lawrence, G. B., Bulger, A. J., Butler, T. J., Cronan, C. S., Eagar, C., Lambert, K. F., Likens, G. E., Stoddard, J. L., and Weathers, K. C.: Acidic Deposition in the Northeastern United States: Sources and Inputs, Ecosystem Effects, and Management Strategies, Bioscience, 51(3), 180-198, 2001.

Driscoll, C. T., Whitall, D., Aber, J., Boyer, E., Castro, M., Cronan, C., Goodale, C. L., Groffman, P., Hopkinson, C., Lambert. K., Lawrence, G., and Ollinger, S.: Nitrogen Pollution in the Northeastern United States: Sources, Effects, and Management Options, Bioscience, 53(4), 357-374, 2003.

Dudhia, J.: Numerical study of convection observed during the winter monsoon experiment using a mesoscale two-dimensional model, J. Atmos. Sci., 46, 3077-3107, 1989.

Fang, Y., Fiore, A. M., Horowitz, L. W., Levy, H. II., Hu, Y., and Russell, A. G.: Sensitivity of the NOy budget over the United States to anthropogenic and lightning NOx in summer, J. Geophys. Res., 115, D18312, doi:10.1029/2004JD005556, 2010.

Fenn, M. E., Baron, J. S., Allen, E. B., Rueth, H. M., Nydick, K. R., Geiser, L., Bowman, W. D., Sickman, J. O., Meixner, T., Johnson, D. W., and Neitlich, P.: Ecological Effects of Nitrogen Deposition in the Western United States, Bioscience, 53(4), 404420, 2003.

Foley, K. M., Roselle, S. J., Appel, K. W., Bhave, P. V., Pleim, J. E., Otte, T. L., Mathur, R., Sarwar, G., Young, J. O., Gilliam, R. C., Nolte, C. G., Kelly, J. T., Gilliland, A. B., and Bash, J. O.: Incremental testing of the Community Multiscale Air Quality (CMAQ) modeling system version 4.7, Geosci. Model Dev., 3, 205-226, doi:10.5194/gmd-3-205-2010, 2010.

Geiser, L. H., Jovan, S. E., Glavich, D. A., and Porter, M. K.: Lichen-based critical loads for atmospheric nitrogen deposition in Western Oregon and Washington Forests, USA, Environ. Pollut., 158, 2412-2442, 2010.

Gilliland, A. B., Appel, K. W., Pinder, R., and Dennis, R. L.: Seasonal $\mathrm{NH}_{3}$ emissions for the continental United States: inverse model estimation and evaluation, Atmos. Environ., 40, 49864998, 2006.

Goebes, M. D., Strader, R., and Davidson, C.: An ammonia emission inventory for fertilizer application in the US, Atmos. Environ., 37, 2539-2550, 2003.

Grell, G. A., Dudhia, A. J., and Stauffer, D. R.: A description of the Fifth-Generation PennState/NCAR Mesoscale Model (MM5) NCAR Technical Note NCAR/TN-398+STR, http://www.mmm. ucar.edu/mm5/doc1.html, 1994.

Houyoux, M. R., Vukovich, J. M., Coats Jr., C. J., Wheeler, N. J. M., and Kasibhatla, P.: Emission inventory development and processing for the seasonal model for regional air quality, J. Geophys. Res., 105 (D7), 9079-9090, 2000.

Kain, J. S.: The Kain-Fritsch convective parameterization: An update, J. Appl. Meteor., 43, 170-181, 2004

Kaynak, B., Hu, Y., Martin, R. V., Russell, A. G., Choi, Y., and Wang, Y.: The effect of lightning $\mathrm{NO}_{\mathrm{x}}$ production on surface ozone in the continental United States, Atmos. Chem. Phys., 8, 5151-5159, doi:10.5194/acp-8-5151-2008, 2008.

Koshak, W. J., Solakiewicz, R. J., Blakeslee, R. J., Goodman, S. J., Christian, H. J., Hall, J. M., Bailey, J. C., Krider, E. P., Bateman, M. G., Boccippio, D. J., Mach, D. M., McCaul, E. W., Stewart, M. F., Buechler, D. E., Petersen, W. A., and Cecil, D. J.: North Alabama Lightning Mapping Array (LMA): VHF Source Retrieval Algorithm and Error Analyses, J. Atmos. Ocean. Tech- 
nol., 21, 543-558, 2004.

Lovett, G. M. and Tear, T. H.: Threat from Above: Air Pollution impacts on Ecosystems and Biological Diversity in the Eastern United States. The Nature Conservancy and the Cary institute of Ecosystem Studies (www.ecostudies.org/reprints/Threats_from_ above.pdf), 2008.

Mlawer, E. J., Taubman, S. J., Brown, P. D., Iacono, M. J., and Clough, S. A.: Radiative transfer for inhomogeneous atmosphere: RRTM, a validated correlated-k model for the long-wave, J. Geophys. Res., 102(D14), 16663-16682, 1997.

Ott, L. E., Pickering, K. E., Stenchikov, G. L., Huntrieser, $\mathrm{H}$., and Schumann, U.: Effects of lightning $\mathrm{NO}_{\mathrm{x}}$ production during the 21 July European Lightning Nitrogen Oxides Project storm studied with a three-dimensional cloud-scale chemical transport model, J. Geophys. Res., 112, D05307, doi:10.1029/2006JD007365, 2007.

Otte, T. L., Pouliot, G., Pleim, J. E., Young, J. O., Schere, K. L., Wong, D. C., Lee, P. C. S., Tsidulko, M., McQueen, J. T., Davidson, P., Mathur, R., Chuang, H. Y., DiMego, G., and Seaman, N. L.: Linking the Eta model with the Community Multiscale Air Quality (CMAQ) modeling system to build a national air quality forecasting system, Weather Forecast., 20, 367-384, 2005.
Pleim, J. E.: A combined local and nonlocal closure model for the atmospheric boundary layer. Part I: model description and testing, J. Appl. Meteor. Clim., 46, 1383-1395, 2007a.

Pleim, J. E.: A combined local and nonlocal closure model for the atmospheric boundary layer. Part II: application and evaluation in a mesoscale meteorological model, J. Appl. Meteor. Clim., 46, 1396-1409, 2007b.

Pleim, J. E. and Xiu, A.: Development and testing of a surface flux and planetary boundary layer model for application in mesoscale models, J. Appl. Meteor., 34, 16-32, 1995.

Reisner, J., Rasmussen, R. M., and Bruintjes, R. T.: Explicit forecasting of supercooled liquid water in winter storms using the MM5 mesoscale model, Q. J. Roy. Meteor. Soc., 124, 10711107, 1998.

Xiu, A. and Pleim, J. E.: Development of a land-surface model. Part I: application in a mesoscale meteorological model, J. Appl. Meteor., 40, 192-209, 2001.

Yarwood, G., Roa, S., Yocke, M., and Whitten, G.: Updates to the carbon bond chemical mechanism: CBo5. Final report to the US EPA, RT-0400675, available at http://www.camx.com, 2005.

2002 Census of Agriculture: US Department of Agriculture, US Summary and State Data, vol. 1, Geographic Area Series Part 51, AC-02-A-51, National Agricultural Statistics Service, 2004. 